yellow band near tip; base of tarsi slightly lighter; coxæ and trochanters yellowish or pinkish. Thorax beneath pinkish; venter reddish. First segment of beak brownish yellow, remainder blackish.

Male, about $5 \mathrm{~mm}$. in length; similar to female.

\title{
PROTHETELY IN THE ELATERID GENUS MELANOTUS.
}

\author{
By J. A. Hyslop, \\ Bureau of Entomology, Washington, D. C.
}

Two papers on the abnormal phenomenon termed prothetely appeared last year in Psyche. In one of these papers ${ }^{1}$ six bibliographical references were given on the subject and in the other paper $^{2}$ a seventh was added to this list. Dr. Adam Böving brought another interesting paper on the same subject, published in $1914,{ }^{3}$ to my attenlion, and in looking over the literature two more papers were located. ${ }^{4,5}$

The present paper deals with a very striking case observed at the United States Entomological Laboratory in Hagerstown. The subject was Melanotus communis Gyll.

On May 18, 1915, Mr. J. J. Davis sent the writer fifty-eight living larvæ of Melanotus communis Gyll., collected near Cincinnati, Ohio, with the note that they were found damaging corn on river bottom land. These larvæ were shipped in salve boxes filled with moist Sphagnum moss, and when received were isolated in similar boxes partly filled with moist earth and fed seed corn. The boxes were all placed in galvanized iron trays and the contents examined, cast skins removed, soil moistened when necessary, and new food supplied, weekly. ${ }^{6}$

Strickland ${ }^{7}$ suggested as an explanation of the phenomenon of prothetely that it "is usually caused by keeping the larvæ at an abnormally high temperature." The temperature to which this particular larva was subjected could not have varied to any appre-

1 Williams, F. X., 1914, Psyche, Vol. XXI, p. 126.

2 Barber, H. S., 1914, Psyche, Vol. XXI, p. 190.

${ }^{3}$ Kemner, A., 1914, Ent. Tidsk. (Swedish), Vol. XXV, pt. 1-2, pp. 87-95.

${ }^{4}$ Tragardh, I., 1912, Fauna och Flora, pp. 245-255.

5 Peyerimhoff, P. de, 1911, Bull. Soc. Ent. France, p. 327.

${ }^{6}$ The writer was ably assisted in this work by Messrs. H. L. Parker and W. E. Pennington of the Station staff.

'Strickland, E. H., 1911, Biol. Bull., Vol. 21, pp. 313-327. 
ciable extent from that of the fifty-seven other larvæ of the same series in the same trays. Up to the date of writing, September 23, 1915, three adults have emerged from this material, all of which appear to be perfectly normal, only seven of the larvæ have died and the remainder are moulting normally and feeding freely. In this same type of cage and in the same insectary, we have been carrying on experiments with about 2,000 Elaterid larvæ from all parts of the United States and the West Indies.

However, this is the only instance of prothetely that we have ever observed. The soil with which these cages are filled is all

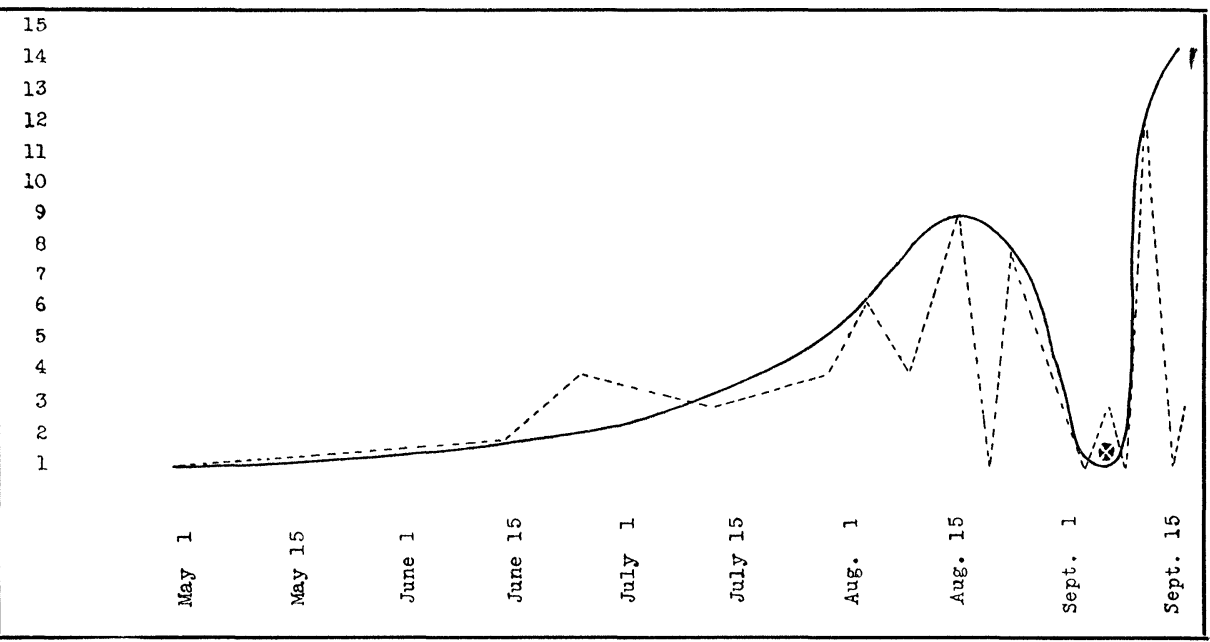

Fig. 1. Plotted curve of Melanotus molting periods. Cross indicates point at which prothetelous larva appeared. The dotted lines connect actual record points.

taken from one potting bench. The amount and kind of food, I believe, can be eliminated as a factor in this particular instance as our larvæ are always supplied with an excess of food. The lids of the boxes, which we use as cages, fit with varying degrees of tightness and the rate of evaporation is, therefore, very inconstant in any given series of cages. On account of this, the cages are only watered when, in the judgment of the examiner, it is necessary. This introduces a large personal factor and could easily result in a cage becoming much more dry or moist than the other cages of the same series. As this seems to be the only variable, I am inclined 
to believe that an abnormal humidity factor at or shortly before the time of pupation is the causative stimulus of this phenomenon.

The accompanying plotted curve (Fig. 1) indicates the period in the activity of the series, when the individual in question transformed to the abnormality herein described. The cages had all been examined on September 3. In examining the cages September 8, the prothetelous larva was discovered. This was a period of minimum moulting immediately preceding a very abrupt and extensive moulting period. The moulted skin of this larva was perfectly normal in every respect and, by careful comparative measurements, was found to be very nearly identical with the last larval skin; that is, the skin shed when a pupa is formed under normal conditions. The table (Fig. 2) shows the measure-

\begin{tabular}{|c|c|c|c|}
\hline & 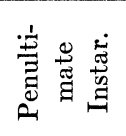 & 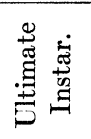 & 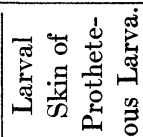 \\
\hline Length of dorsum of 9 th abdominal segment . . & 2.782 & 3.103 & 3.156 \\
\hline Width of dorsum of 9 th abdominal segment. & 1.979 & 2.193 & 2.193 \\
\hline Length of dorsum of 1st thoracic segment... & 1.498 & 1.819 & 1.712 \\
\hline
\end{tabular}

Fig. 2. Table showing comparative measurements of larval skins of penultimate instar, ultimate instar and prothetelous larvæ.

ments of this cast skin as compared with a larval skin from the ultimate and penultimate instar.

This prothetelous larva is (Plate II, Figs. 3, 4, and 5) predominantly larviform. The abdomen is typically so and normally chitinized, with the exception of a pair of membranous papilliform areas on the posterior margin of each sternitie except the ninth (Plate III, Fig. 3). The thoracic sterna are membranous except a triangular area on the prosternum (Plate III, Fig. 5), which is normally chitinized. The membranous areas are decidedly protuberant. The coxæ and trochanters are larviform with typical pupiform femora, tibiæ and tarsi. The ventral part of the protergite is membranous and very much expanded posteriorly. A pair of anterior and a pair of posterior papillæ are borne on the spiracular 
area of the protergum (Plate III, Fig. 5). The mouthparts are all larviform. The basal joint of the antennæ is larviform and chitinized; the remainder of the antennæ is membranous and typically pupiform. The eyes are typically pupiform with a membranous area surrounding t'hem, which connects the eye with the larviform cheeks. The wing pads are well developed, but the elytral pads do not bear the normal striation found in typical pupa. The base of the wing pads is surrounded by a membranous area and the pads seem to arise in the spiracular area. The specimen measures $23 \mathrm{~mm}$. in length, the dorsum of the ninth abdominal segment measures $2.996 \mathrm{~mm}$. in length, and $2.14 \mathrm{~mm}$. in width. The first thoracic tergite is $1.498 \mathrm{~mm}$. long.

This particular case of prothetely seems to be a carrying forward of larval characters into the pupal stage rather than a carrying back of pupal characters into the larval stages. Such being the case, it is possible and even probable that by the successful emergence of such a pupa some larval characters would be carried into the adult stage, and if such characters were of some material advantage to their possessors natural selection might here find variations which could lead to the production of such species with larviform adults as do exist in certain other Coleopterous genera.

\title{
TWO NEW THYSANOPTERA FROM WEST AFRICA, WITH A NOTE ON THE SYNONYMY OF THE PHLEOTHRIPIDAE.
}

\author{
By J. Douglas Hood, \\ United States Biological Survey, Washington, D. C.
}

The new species described below were sent to me in October, 1915, from Ossidinge, Kamerun, by Lieut. A. W. Jobbins-Pomeroy, of the Nigeria Regiment, West African Frontier Force. Partly in recognition of his devotion to entomology under such adverse circumstances, and partly as a mark of personal regard, I have taken great pleasure in naming one of the species in his honor. 


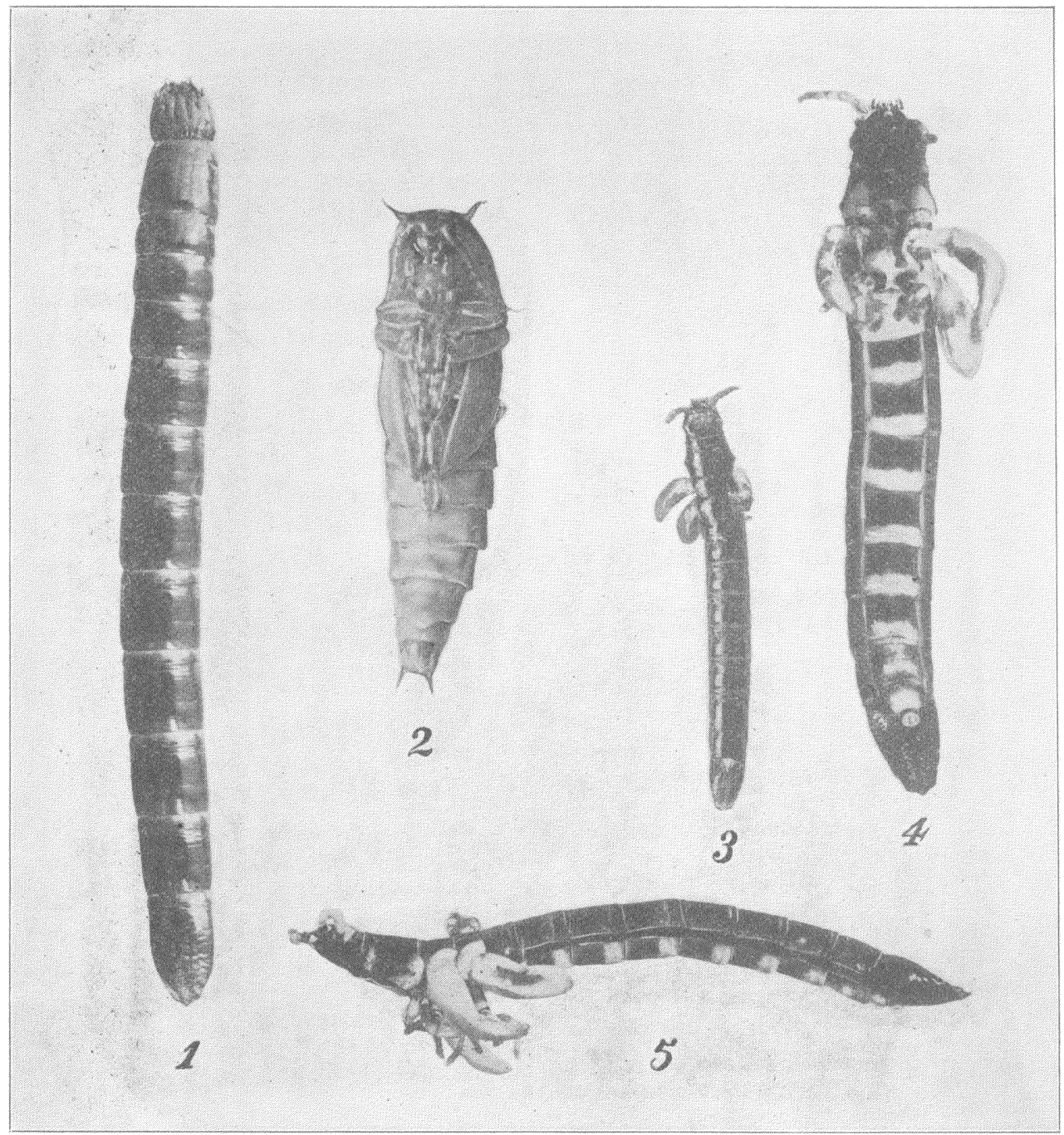

Normal and prothetelous larva and normal pupa of Melanotus communis. Fig. 1, dorsum of normal larva. Fig. 2, ventron of pupa. Fig. 3, dorsum of prothetelous larva. Fig. 4, ventron of prothetelous larva. Fig. 5, lateral aspect of prothetelous larva. 

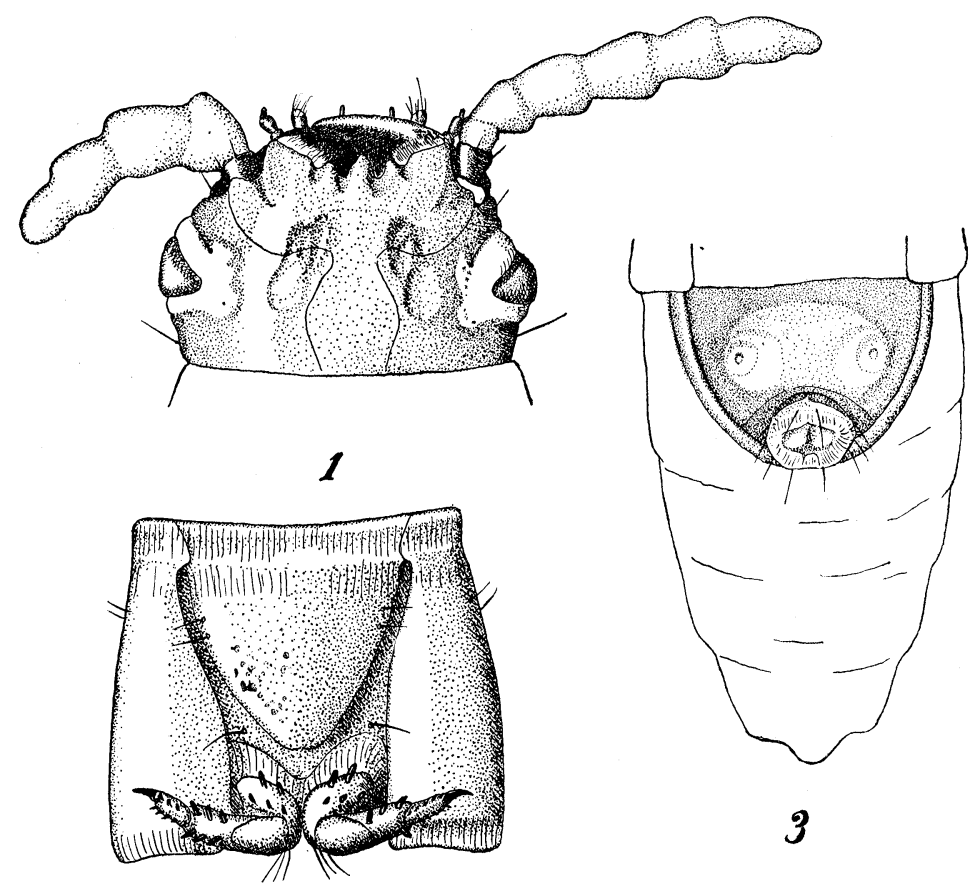

2
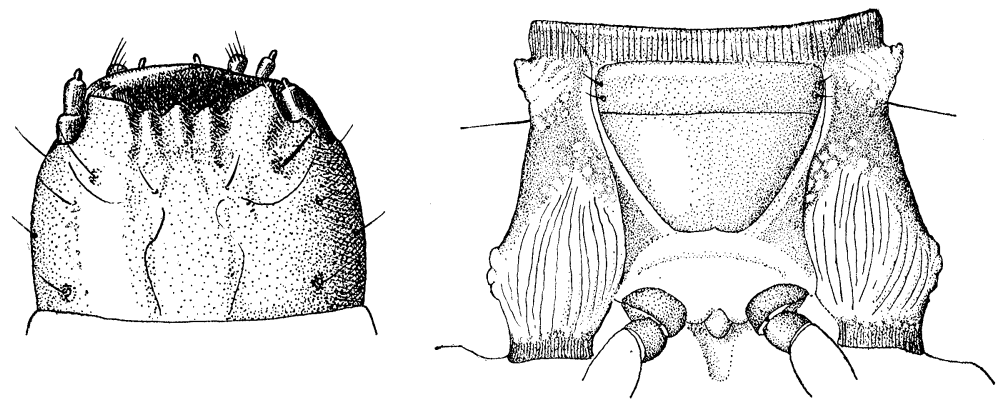

4

5

Me'anotus communis normal and prothetelous larva. Fig. 1, dorsum of the head of prothetelous larva. Fig. 2, prosternum of normal larva. Fig. 3, 9th and 10th abdominal segments of prothetelous larva. Fig. 4, dorsum of head of normal larva. Fig. 5, prosternum of prothetelous larva. 

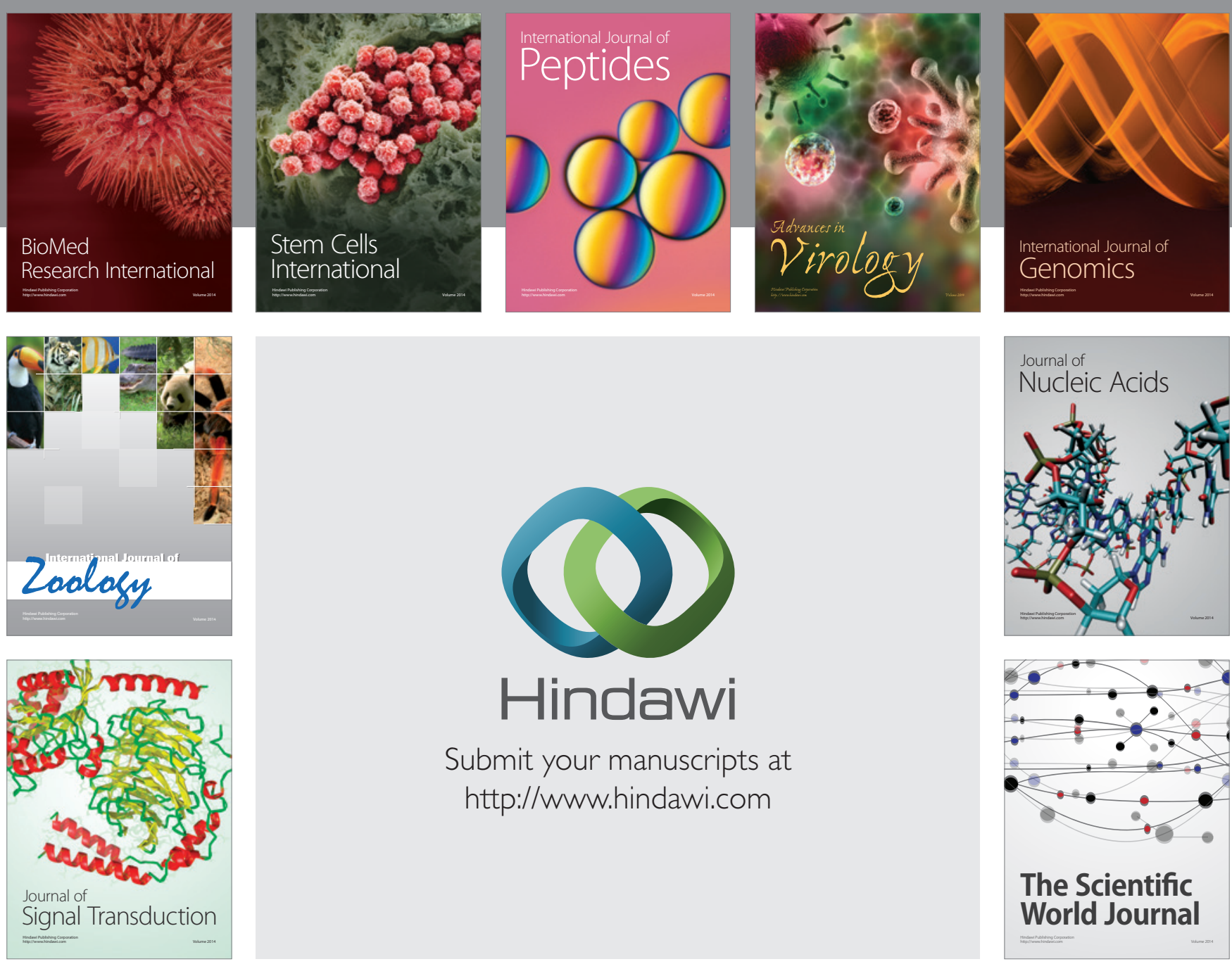

Submit your manuscripts at

http://www.hindawi.com
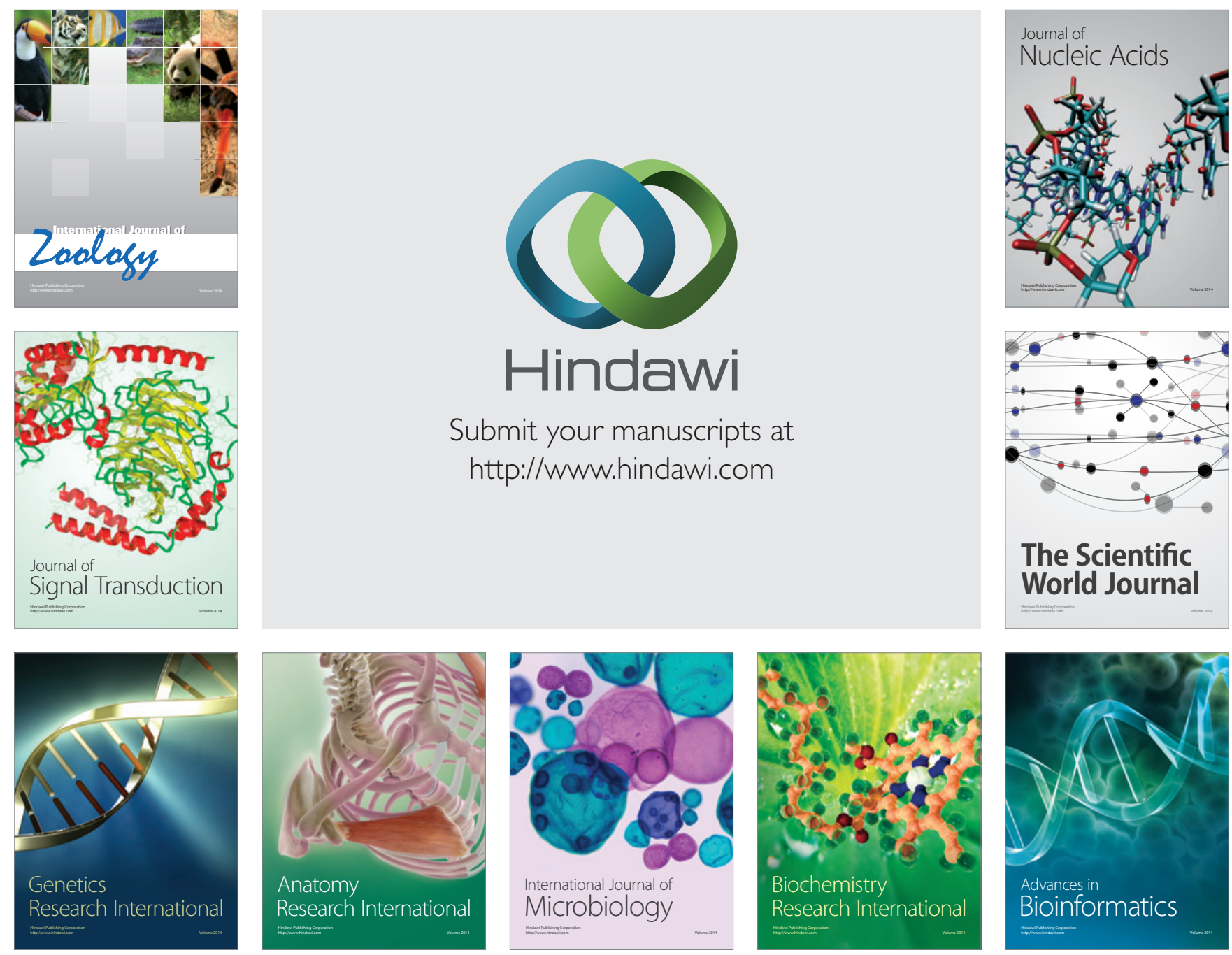

The Scientific World Journal
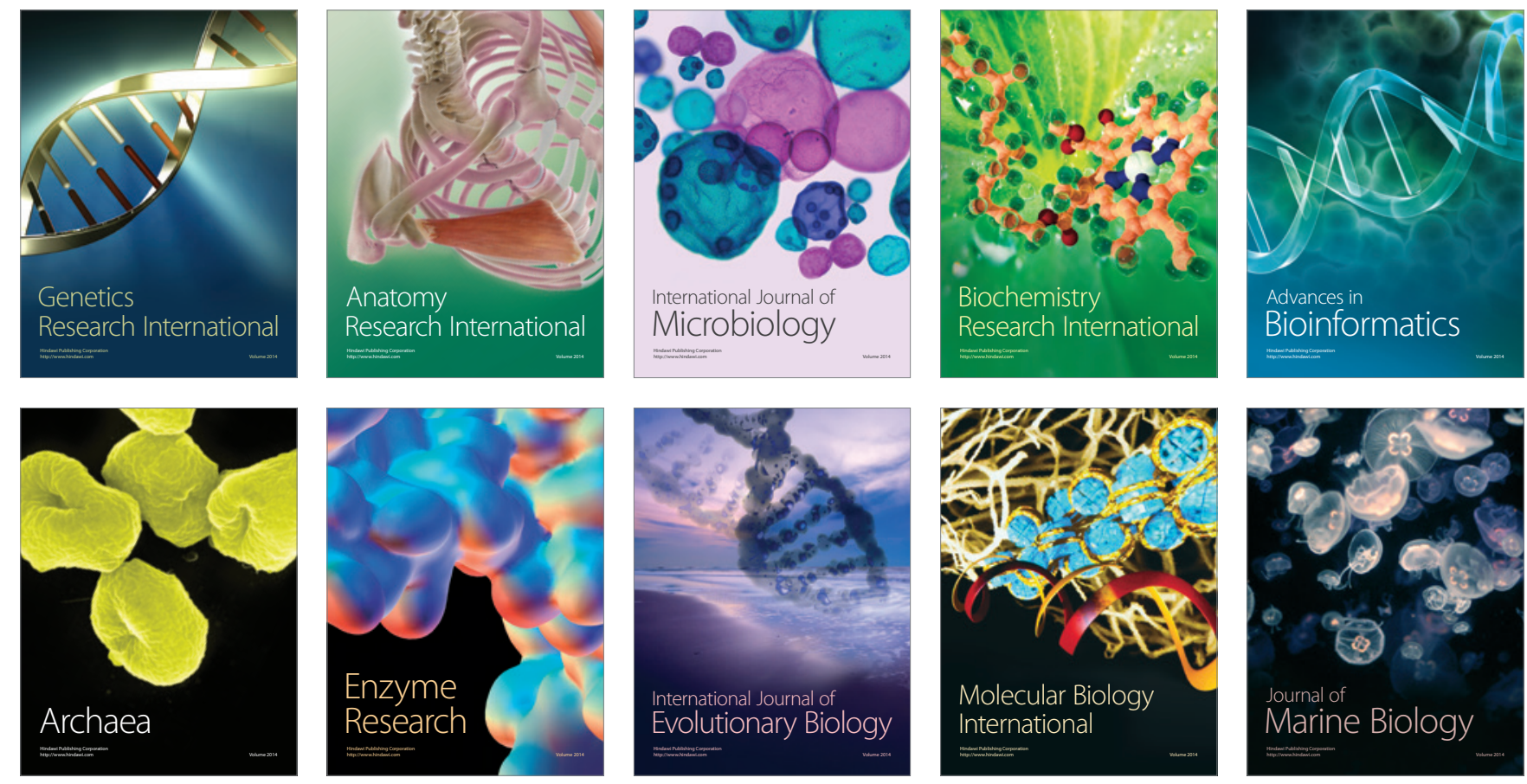